\title{
SOME THOUGHTS ABOUT CURRENT \\ PROBLEMS IN LEGAL ETHICS AND \\ PROFESSIONAL \\ RESPONSIBILITY*
}

\author{
Harold C. Petrowitz**
}

The legal profession is presently in an embattled position concerning inatters of ethics and professional responsibility. It has been the target of stimging criticisin from the President of the United States, ${ }^{1}$ the Chief Justice of the United States, ${ }^{2}$ and others. Reliable surveys indicate that the profession stands at an appallingly low level of public esteein. ${ }^{3}$ Some of the reasons for this poor reputation can be traced to a public perception of the profession as greedy and self-serving. Many of the pohicies of the profession that have engendered this response are regulated by the present Code of Professional Responsibility as it is articulated and interpreted by the American Bar Association.

The Code of Professional Responsibility addresses the full spectrum of professional activities that the practicing bar engages in and lays down specific rules for dealing with ethical matters. This discussion will focus on three of the more troublesome and controversial areas of legal ethics and professional responsibihty relatimg to the lawyer's obligations to his chent: preserving confidences of individual and organizational clients, inaking disclosures to the relevant tribunal

* This Article is based on remarks on current problems in legal ethics and professional responsibility at the Duke University School of Law Symposium on Professional Responsibility held in Durham, North Carolina, on October 20, 1979.

** Professor of Law, American University. B.S. 1943, University of Michigan; LL.B. 1950, Georgetown University; LL.M. 1962, Columbia University. The author gratefully acknowledges the research assistance of Mr. Mark Abramson, a student at the American University Law School, in the preparation of this Article.

THE FOLLOWING CITATIONS WILL BE USED IN THIS ARTICLE:

ABA Code of Professional Responsibility (1978) [Disciplinary Rules and Ethical Considerations therein hereinafter cited only by DR and EC numbers];

Text of Initial Draft of Ethics Code Rewrite Committee, Legal Times of Wash., Aug. 27, 1979, at 26, col. 1 [hereinafter cited as Legal Times].

1. N.Y. Times, May 5, 1978, $\S \mathrm{A}$, at 1 , col. 5 (news story); id. $\S \mathrm{A}$, at 15, col. 1 (excerpts from speech).

2. Address by Chief Justice Warren E. Burger, 9 th Circuit Judicial Conference, Sun Valley, Idaho (July 23, 1979), reprinted in Burger, The State of the Federal Judiciary 1979, 65 A.B.A.J. 358 (1979).

3. Gallup Opinion Index, Report 150, at 8, 17 (Jan., 1978). 
that may be agamst the interest of the client but required if a miscarriage of justice is to be prevented, and avoiding conflicts of interest by government lawyers who resign their positions to enter private practice.

Althougl all three of these matters are related, there is a particularly close tie between preserving client confidences and making disclosures to the tribunal because these ethical considerations dramatize the competing obligations of the lawyer to the client and to the justice system. ${ }^{4}$

The principle that communications between the client and his lawyer are privileged and thus protected against disclosure is rooted in the idea that the client must feel free-and, indeed, be encouraged-to disclose every facet of his problem to the counselor and advocate charged with the responsibility of securing for him the remedies and safeguards of the judicial system. It is cminently logical that nothing should stand im the path of the lawyer in protectimg the interests of his client; nevertheless, the unrestrained application of this important principle can bring the lawyer into conflict with the public imterest in having the justice system function effectively and efficiently.

Suppose, for example, that the client discloses the fact that he intends to commit a serious crine against the person or property of another. Or suppose that a lawyer acquires information that another member of the bar has violated a rule that subjects that meinber to disciplimary action. What are the obligations of a lawyer wlio acquires such information?

DR 4-101 of the existing ABA Code of Professional Responsibility deals with the first supposition. ${ }^{5}$ This rule makes it clear that the law-

4. The term "justice system" is intended to refer to the established mechanism for application and enforcement of the law and for resolution of controversies. There is a very high level of public interest in the effective and efficient functioning of this system.

5. The relevant parts of that rule state:

DR 4-101 Preservation of Confidences and Secrets of a Client.

(A) "Confidence" refers to information protected by the attorney-chent privilege under applicable law, and "secret" refers to other information gained in the professional relationship that the client has requested be held inviolate or the disclosure of which would be embarrassing or would be likely to be detrimental to the client.

(B) Except when permitted by $D R$ 4-101(C), a lawyer shall not knowingly:

(1) Reveal a confidence or secret of his chient.

(2) Use a confidence or secret of his client to the disadvantage of the client.

(3) Use a confidence or secret of his client for the advantage of himself or of a third person, unless the client consents after full disclosure.

(C) A lawyer may reveal:

(1) Confidences or secrets with the consent of the client or clients affected, but only after a full disclosure to them.

(2) Confidences or secrets when permitted under Disciplinary Rules or required by law or court order.

(3) The intention of his client to commit a crime and the information nccessary to prevent the crime.

(4) Confidences or secrets necessary to establish or collect his fee or to defend 
yer is not required to disclose any confidences or secrets of his client even if the client consents. Although it is true that two formal opinions of the American Bar Association have identified situations in which the lawyer must disclose the confidences of the client, ${ }^{6}$ the fact remains that the language of DR 4-101 itself is clear and unequivocal; it is not qualified in any way by the "ethical considerations" that precede it.7 Nor has the rule been explicitly limited by any formal opinion specifically interpreting it. The rule should be clarified to make certain that the Code does not require an attorney to become an accessory before the fact of the chient's crime.

DR 1-103 covers the second supposition. It requires a lawyer possessing unprivileged knowledge of another lawyer's violation of DR 1102 to report the violation to appropriate governing authorities. ${ }^{8}$ Again

himself or his employees or associates against an accusation of wrongful conduct.

DR 4-101 (Emphasis added) (footnotes omitted).

6. In ABA Comm. on Professional Ethics, Opinions, No. 314, at 688 (1965), which referred to practice before the Internal Revenue Service, this sentence is found:

Nor does the absolute duty not to make false assertions of fact require the disclosure of weaknesses in the client's case and in no event does it require the disclosure of his confdences, unless the facts in the attorney's possession indicate beyond reasonable doubt that a crime will be committed.

Id. 691 (einphasis added).

It should be noted that the underscored words bear only a tenuous relation to the main subject of the opinion, which is an interpretation of old Canon 15, adopted by the ABA in 1908, admonishing the lawyer to use "warm zeal" in representing the chient. DR 7-101 of the present code incorporates most of the substance of old Canon 15. It is interesting to note that, although Opinion 314 prohibits the lawyer from actively perpetrating fraud or violating the law in representing a chent before the Internal Revenue Service, it stops short of requiring the lawyer to disclose antecedent fraud or inisrepresentation by the client.

See also ABA Comm. on Professional Ethics, Opinions, No. 155, at 426 (1936), which held that an attorney whose client has fled the jurisdiction of the court while out on bail must reveal the whereabouts of his client even if that imfornation was received in confidence. Opinion 155 also states:

When the communication by the client to his attorney is in respect to the future commission of an unlawful act or to a continuing wrong, the communication is not privileged. One who is actually engaged in committing a wrong can have no privileged witnesses, and public policy forbids that an attorney should assist in the commission thereof, or Id.

permit the relation of attorney and client to conceal the wrongdoing.

7. In the present fornat of the Code, each disciplimary rule is accompanied by several prefatory paragraphs referred to as "ethical considerations." These stateinents are explanatory, not mandatory as are the disciplimary rules.

8. The full text of DR 1-102 and DR 1-103 follows:

DR 1-102 Misconduct.

(A) A lawyer shall not:

(1) Violate a Disciplinary Rule.

(2) Circumvent a Disciplinary Rule through actions of another.

(3) Engage in illegal conduct involving moral turpitude.

(4) Engage in conduct involving dishonesty, fraud, deceit, or misrepresentation.

(5) Engage in conduct that is prejudicial to the administration of justice. 
the disclosure requirement is limited to knowledge derived from unprivileged communications and thus specifically excludes chent confidences and secrets. This rather specialized provision thus weaves a pattern that is consistent with DR 4-101. Some jurisdictions, such as North Carolina, have further modified this rule to make disclosure of unprivileged knowledge optional rather than mandatory. ${ }^{9}$

DR 7-102 addresses the requirement of disclosure to the tribunal affecting the interests of the client. ${ }^{10}$ This rule requires the lawyer to reveal to the tribunal or affected person any fraud perpetrated by his client against the tribunal or person, except when the revelation involves privileged communication. ${ }^{\text {1 }}$ Although its meaning was uncertain froin 1969 until the issuance of a clarifying amendment in 1974, there can now be no doubt that the rule forbids the disclosure of client confidences and secrets even when the failure to disclose will result in a iniscarriage of justice. This conclusion is buttressed by Formal Opinion 341 of the ABA Committee on Ethics and Professional Responsibility. ${ }^{12}$ This Opinion makes it absolutely clear that confidentiality of privileged comnunications must be preserved even though the miscar-

(6) Engage in any other conduct that adversely reflects on his fitness to practice law.

DR 1-103 Disclosure of Information to Authorities.

(A) A lawyer possessing unprivileged knowledge of a violation of DR 1-102 shall report such knowledge to a tribunal or other authority empowered to investigate or act upon such violation.

(B) A lawyer possessing unprivileged knowledge or evidence concerning another lawyer or a judge shall reveal fully such knowledge or evidence upon proper request of a tribunal or other authority empowered to investigate or act upon the conduct of lawyers or judges.

9. North Carolina Code of Professional Responsibility DR 1-102, reprinted in N.C. Gen. Stat. vol. 48, app. VII (Cum. Supp. 1977).

10. The relevant provisions of $D R$ 7-102 are as follows:

DR 7-102 Representing a Client Within the Bounds of the Law.

(A) In his representation of a client, a lawyer shall not:

(3) Conceal or knowingly fail to disclose that which he is required by law to reveal.

(4) Knowingly use perjured testimony or false evidence.

(B) A lawyer who receives information clearly establishing that:

(1) His client has, in the course of the representation, perpetrated a fraud upon a person or tribunal shall promptly call upon his client to rectify the same, and if his client refuses or is unable to do so, he shall reveal the fraud to the affected person or tribunal, except when the information is a privileged communication.

11. The concluding phrase of DR 7-102(B)(I), which reads "except when the information is a privileged communication," was added by amendment in 1974 in response to complaints by some members of the bar that the rule as originally adopted, when combined with DR 4-101(C), see note 5 supra, might oblige them to violate the law of evidence. The meaning of this complaint is not entirely clear, but it is the explanation for the change given in ABA COMM. ON PROFESSIONAL ETHICS, OpINIONs, No. 341 (1975). See note 13 infra.

12. Promulgated Sept. 30, 1975. See note 11 supra. 
riage of justice resulting froin nondisclosure might be substantial. ${ }^{13}$

The requirement of confidentiahty bears down particularly hard on the lawyer who represents the board of directors of a corporation. The rule absolutely precludes him froin "blowing the whistle" on a corrupt board of directors by disclosing their wrongdoing to the stockholders or to the Securities and Exchange Commission or another regulatory agency. This prohibition against speaking up can jeopardize the existence of the corporation.

The conclusion that inust be drawn from this review of the tensions created by the lawyer's coinpeting obligations to the client and to the justice system unmistakably indicates that the present ABA Code of Professional Responsibility inakes the lawyer's duty to the chent his paramount responsibility. Although this policy undoubtedly supports one of the long-standing traditions of the legal profession, it is also certain to generate conflicts with the community in which lawyers must function.

Another important ethical problem affecting lawyers is the conflict of interest that can develop when circumstances place former, present, or prospective clients in adversarial relationships with each other. Such circumstances can put the lawyer's personal imterests in taking advantage of einployment opportunities im direct conflict with the client's imterest in preserving confidences and loyalty. Simple logic tells us that the lawyer cannot simultaneously or sequentially represent clients who are adversaries. Under the Disciplinary Rules, if two clients, either past or present, become adversaries, the lawyer must sever his relationship with one of thein, except under strictly controlled circumstances. ${ }^{14}$

13. ABA Opinion 341 was issued in response to inquiries regarding the 1974 amendment to DR 7-102(B)(1), see note II supra. DR 7-102(B)(1) in its original form (without the concluding phrase) was a last mimute addition to the Code of Professional Responsibility promulgated in 1970. It was inserted at the request of nany members of the bar to carry into the new code the requirement of disclosing client fraud and deception that was contamed in Canon 41 of the prior Canons of Professional Ethics. The absence of the phrase "except when the information is a privileged communication" caused lawyers to become concerned that the original text of DR 7102(B)(1) required disclosure of client confidences. Opinion 341 removed all doubt as to the overriding priority of safeguarding client confidences.

A sinilar probleun had developed with the prior Canons of Professional Ethics. Canon 37 required preservation of client confidences, Canon 29 required disclosure of client perjury, and Canon 41 required disclosure of client fraud. ABA Opinion 287 was issued in 1953 to resolve the apparent conflict in connection with client perjury in a divorce case. This opinion, like its successor 341 , left no doubt that client confidences were to be preserved even at the expense of other canons.

14. DR 5-105 provides:

DR 5-105 Refusing to Accept or Continue Employment if the Interests of Another Client May Impair the Independent Professional Judgment of the Lawyer.

(A) A lawyer shall decline proffered employinent if the exercise of his independent professional judgment in behalf of a client will be or is likely to be adversely af- 
This problem becomes particularly acute when a government official decides to resign from his public employment and enter private practice. Disciplinary Rule 9-101 addresses this problem by laying down the well recognized principle that a lawyer shall not accept private employinent in a inatter in which he had substantial responsibility while he was a public employee. ${ }^{15}$ In the case of federal government lawyers, this principle is reinforced by the federal conflict of interest statute ${ }^{16}$ as amended and strengthened by the Ethics in Government Act of $1978 .{ }^{17}$

fected by the acceptance of the proffered employment, or if it would be likely to involve him in representing differmg interests, except to the extent permitted under DR 5-105(C).

(B) A lawyer shall not continue multiple employment if the exercise of his independent professional judgment in behalf of a client will be or is likely to be adversely affected by his representation of another client, or if it would be likely to involve him in representing differing interests, except to the extent permitted under DR 5$105(\mathrm{C})$.

(C) In the situations covered by DR 5-105(A) and (B), a lawyer may represent multiple clients if it is obvious that he can adequately represent the interest of each and if each consents to the representation after full disclosure of the possible effect of such representation on the exercise of his independent professional judgment on behalf of each.

(D) If a lawyer is required to decline employment or to withdraw from employment under a Disciplinary Rule, no partner, or associate, or any other lawyer affiliated with him or his firm, may accept or continue such employment.

(footnotes omitted).

15. The full text of DR 9-101 reads as follows:

DR 9-101 Avoiding Even the Appearance of Impropriety.

(A) A lawyer shall not accept private employment in a matter upon the merits of which he has acted in a judicial capacity.

(B) A lawyer shall not accept private employment in a matter in which he had substantial responsibility while he was a public employee.

(C) A lawyer shall not state or imply that he is able to influence improperly or upon irrelevant grounds any tribunal, legislative body, or public official.

(footnotes omitted).

16. 18 U.S.C. $\$ \S 201-224$ (1976). Section 207 of this statute imposes criminal penalities on those who violate its post-government employment disqualifications.

17. Pub. L. No. 95-521, 92 Stat. 1824 (codifled at 18 U.S.C.A. $\$ 207$ (West Supp. 1979)), as amended by Pub. L. No. 96-28, 93 Stat. 76 (1979) (to be codified in 18 U.S.C. \$ 207). As the beefed-up conflict of interest statute now stands, section 207 reads in pertinent part:

$\$ 207$. Disqualification of former officers and einployees; disqualification of partners of current officers and einployees

(a) Whoever, having been an officer or employee of the executive branch of the United States Governinent, of any independent agency of the United States, or of the District of Columbia, including a special Government employee, after his employment has ceased, knowingly acts as agent or attorney for, or otherwise represents, any other person (except the United States), in any formal or informal appearance before, or with the intent to influence, makes any oral or written communication on behalf of any other person (except the United States) to-

(1) any department, agency, court, court-martial, or any civil, military, or naval commission of the United States or the District of Columbia, or any officer or employee thereof, and

(2) in connection with any judicial or other proceeding, application, request for a ruling or other determination, contract, claim, controversy, investigation, charge, accusation, arrest, or other particular matter involving a specific party or parties in which the United States or the District of Columbia is a party or has a direct and substantial interest, and 
The federal courts have traditionally been highly sensitive to con-

(3) in which he participated personally and substantially as an officer or employee through decision, approval, disapproval, recommendation, the rendering of advice, investigation or otherwise, while so employed; or

(b) Whoever, (i) having been so employed, within two years after his employment has ceased, knowingly acts as agent or attorney for, or otherwise represents, any other person (except the United States), in any formal or informal appearance before, or, with the intent to infuence, makes any oral or written communication on behalf of any other person (except the United States) to, or (ii) having been so employed and as specified in subsection (d) of this section, within two years after his employment has ceased, knowingly represents or aids, counsels, advises, consults, or assists in representing any other person (except the United States) by personal presence at any formal or informal appearance before-

(1) any department, agency, court, court-martial, or any civil, military or naval commission of the United States or the District of Columbia, or any officer or employee thereof, and

(2) in connection with any judicial or other proceeding, application, request for a ruling or other determination, contract, claim, controversy, investigation, charge, accusation, arrest, or other particular matter involving a specific party or parties in which the United States or the District of Columbia is a party or has a direct and substantial interest, and

(3) as to (i), which was actually pending under his official responsibility as an officer or employee within a period of one year prior to the termmation of such responsibility, or as to (ii), in which he participated personally and substantially as an officer or employee; or

(c) Whoever, other than a special Government enployee who serves for less than sixty days in a given calendar year, having been so employed as specified in subsection (d) of this section, within one year after such employineut has ceased, knowingly acts as agent or attorney for, or otherwise represents, anyone other than the United States in any formal or informal appearance before, or, with the intent to influence, unakes any oral or written comununication on behalf of anyone other than the United States, to-

(1) the departinent or agency in which he served as an officer or employee, or any officer or employee thereof, and

(2) in connection with any judicial, rulennaking, or other proceeding, application, request for a ruling or other determination, contract, claim, controversy, investigation, charge, accusation, arrest, or other particular matter, and

(3) which is pending before such department or agency or in which such department or agency has a direct and substantial interest-

shall be fined not more than $\$ 10,000$ or imprisoned for not unore than two years, or both.

(g) Whoever, being a partner of an officer or employee of the executive branch of the United States Government, or any independent agency of the United States, or of the District of Columbia, including a special Government employee, acts as agent or attorney for anyone other than the United States before any department, agency, court, courtmartial, or any civil, military, or naval commission of the United States or the District of Columbia, or any officer or employee thereof, in connection with any judicial or other proceeding, application, request for a ruling or other determination, contract, claim, controversy, investigation, charge, accusation, arrest, or other particular matter in which the United States or the District of Columbia is a party or has a direct and substantial interest and in which such officer or employee or special Government employee participates or has participated personally and substantially as an officer or employee through decision, approval, disapproval, recounmendation, the rendering of advice, investigation, or otherwise, or which is the subject of his official responsibility, shall be fined not more than $\$ 5,000$, or imprisoned for not more than one year, or both.

(j) If the head of the department or agency in which the former officer or einployee served finds, after notice and opportunity for a hearing, that such former officer or employee violated subsection (a), (b), or (c) of this section, such department or agency head may prohibit that person from making, on behalf of any other person (except the United States), any informal or formal appearance before, or, with the intent to influeuce, any oral or written communication to, such department or agency on a pending matter of business for a period not to exceed five years, or inay take other appropriate disciplinary 
flict of interest problems involving lawyers who represent clients before the agency formerly served by the lawyer as a government employee. Some of these decisions have applied appropriate sections of the Code of Professional Responsibility as the basis for individual disqualification $^{18}$ and vicarious disqualification. ${ }^{19}$ No cases have been found applying the fcderal conflict of interest statute, primarily because of the problems of proof in securing criminal convictions under this statute. ${ }^{20}$

The problein of post-employment disqualification of public employees became acute in 1974 when the ABA amended DR 5-105(D) to disqualify vicariously partners and associates of any lawyer required to withdraw from employinent under any disciplinary rule. ${ }^{21}$ This meant that if a former public employee who had become a member of a law firm was disqualified from employinent under DR 9-101(B), ${ }^{22}$ every other member of the law flrn would also be disquahfled by the application of the vicarious disqualification rule, DR 5-105(D).

Strict application of these rules could be devastating to a law firm

action. Such disciplinary action shall be subject to review in an appropriate United States district court. No later than six months after the effective date of this Act, departments and agencies shall, in consultation with the Director of the Office of Government Ethics, establish procedures to carry out this subsection.

18. See, e.g., General Motors Corp. v. City of New York, 501 F.2d 639 (2d Cir. 1974) (former attorney in Antitrust Division of U.S. Department of Justice disqualified under DR 9-101); Allied Realty of St. Paul, Inc. v. Exchange Nat'l Bank, 408 F.2d 1099 (8th Cir.), cert. denied, 396 U.S. 823 (1969) (former Assistant U.S. Attorney disqualified under Code); Telos, Inc. v. Hawaiian Tel. Co., 397 F. Supp. 1314 (D. Haw. 1975) (former attorney with state antitrust division disqualified under provisions of Code).

19. See, e.g., Cinema S, Ltd. v. Cinerama, Inc., 528 F.2d 1384 (2d Cir. 1976) (law firm in New York City disqualified from representing plaintiff under DR 9-101 where a Buffalo, N.Y. firm having common partner with New York City firm represented defendant); Handelman v. Weiss, 368 F. Supp. 258 (S.D.N.Y. 1973) (law firm disqualified under DR 5-105(D) where member of firm had access to information possessed by opposing parties).

20. See note 17 supra. The most fanous case applying federal law to post-employment disqualification was United States v. Mississippi Valley Generating Co., 364 U.S. 520 (1961). This was the Dixon-Yates case in which the Supreme Court held a government contract void and of no effect because an official of the bank arranging the financing for a power plant being built for the Atomic Energy Comnission was serving (without salary) in the Bureau of the Budget at the time of awarding the contract. The statute involved was 18 U.S.C. $\S 434$ (1958), which was repealed by the comprehensive conflict of interest statute that became law in 1963.

21. For the text of DR 5-105(D) as it now reads, see note 14 supra. Prior to 1974, DR 5105(D) read as follows:

(D) If a lawyer is required to decline employment or to withdraw from employment under DR 5-105, no partner or associate of his firm may accept or continue such employment.

In this form, the rule had applied vicarious disqualification only to situations in which a partner or associate was required to refuse employment because of a clear conflict of interest under DR 5105(B).

22. See note 15 supra for the text of this rule, which permanently disquahifies a lawyer from private employment in any matter over which he had substantial responsibility while a public employee. 
specializmg in claims arising from government contracts that hired as a partner a former general counsel of the Department of Defense or the Administrator of General Services. Nor would a law firm engaged primarily im securities work be safe im hiring a former official of the Securities and Exchange Commission who had decided to forsake government einployment and seek his fortune in private law practice.

At issue in situations of this kind are the competing imterests of clients in preventing the disadvantageous disclosure of their confidences and of lawyers im maximizing for themselves their opportunities for advantageous employment. The balance struck has great impact on the long-term ability of the federal government to attract capable people into public service. Despite its tendency to deter acceptance of government employment and to limit lawyer employability, however, the vicarious disqualification rule cannot be regarded as mappropriate. It has been recognized as an ethical rule of the legal profession for many years, even antedating the first ABA canons of 1908. In addition, it accurately reflects both the extremely close relationship that necessarily exists between the members of a modern law firm and the manner im which that relationship might affect client representation. ${ }^{23}$

The American Bar Association endeavored to nnitigate the problems caused by the rule by promulgating Opinion 342 in 1975. This Opinion recognizes that unduly severe restraints should not be imposed on the lawyer's opportunities for employinent after he leaves government service. It suggests that a "reahstic" interpretation be given to the meaning of "substantial responsibility" in the application of DR 9-101(C), and approves a process of avoiding disqualification of the entire firm by "screening" the disqualified member to the satisfaction of the government agency with which he was formerly employed.

The United States Court of Claims has endorsed the screening

23. In Laskey Bros. of W. Va., Inc. v. Warner Bros. Pictures, 224 F.2d 824 (2d Cir. 1955), the Second Circuit affirmed the disqualification of a law firm, stating: "[A]ll authorities agree that all meinbers of a partnership are barred from participating in a case from which one partner is disquahified." Id. at 826. In making this assertion, the court relied im part on Consolidated Theatres, Inc. v. Warner Bros. Circuit Management Corp., 216 F.2d 920 (2d Cir. 1954). See also W.E. Basset Co. v. H.C. Cook Co., 201 F. Supp. 821 (D. Conn.), aff'd, 302 F.2d 268 (2d Cir. 1962).

Although the court in United States v. Standard Oil Co., 136 F. Supp. 345 (S.D.N.Y. 1955), ruled that the partner who was a former government einployee did not have knowledge sufficient to disqualify him, it stated in footnote 4 of its opinion: "It is conceded by Sullivan \& Cromwell that if $\mathrm{Mr}$. Horn is disqualified, the entire firm is disqualified. The reasons for this will be discussed infra in relation to the inputed knowledge within a partnership." Id. at 350 n.4. In Silver Chrysler Plymouth, Inc. v. Chrysler Motors Corp., 370 F. Supp. 581 (E.D.N.Y. 1973), aff'd, 518 F.2d 751 (2d Cir. 1975), the court clearly recognized the vicarious disqualification rule but held it to be a rebuttable presumption in certain cases. 
process in one recent decision. ${ }^{24}$ The United States Court of Appeals for the Second Circuit, however, in Armstrong v. McAlpin, ${ }^{25}$ a resounding decision issued on September 12, 1979, virtually demolished the screening process as a device for avoiding vicarious disqualification of a firm, one of whose menibers is disqualified by DR 9-101(B). The court pointed out that the type of activity justifying disqualification of the former government employee turned law firm partner was "precisely the sort of activity where the risk of being influenced by the prospect of future employment is very real." 26 For this reason no screening procedure could suffice to prevent disqualification of the former government employee's firm. The Securities and Exchange Commission, which filed an amicus brief in the Armstrong case, asked the Second Circuit for a rehearing en banc which has been granted. Regardless of the outcome of the rehearmg, the case inay go to the United States Supreme Court for ultimate resolution. Whatever the outcoine, the controversy has thrown a major seginent of the practicing bar into a state of consternation, particularly in Washington, D.C., where a sizeable number of practitioners are former government employees.

One possible solution to the problem is for the governing bodies of the bar in the various jurisdictions to annend DR 5-105(B), the vicarious disqualification provision, to its original, pre-1974, wording. At least one jurisdiction has done this, thus limiting the reach of vicarious disqualification to cases of unmistakable conflict of interest. ${ }^{27}$ Such a

24. Kesselhaut v. United States, 555 F.2d 791 (Ct. Cl. 1977). Reversing the ruling of the trial judge, the court held that although the former Federal Housing Administration employee now a partner in a law firm representing a chent in a claim against the FHA was disqualified, he had bcen sufficiently screened from the other firm members so as not to disqualify the entire firm.

25. 606 F.2d 28 (2d Cir. 1979), rehearing en banc granted, No. 79-7042 (2d Cir. Dec. 12, 1979). The plaintiff in this case was Armstrong, who had been appointed receiver for Capital Growth Company. The Securities and Exchange Commission had filed a complaint against Capital Growth Company for violations of $\$ 10(\mathrm{~b})$ of the Securities and Exchange Act of 1934, 15 U.S.C. $\$ 78 j$ (b) (1976), and Rule 10b-5, 17 C.F.R. $\$ 240.10 b-5$ (1979). Altman, formerly Assistant Director of the Securities and Exchange Commission Division of Enforcement, supervised the investigation that resulted in the complaint and then left the Securities and Exchange Commission to join the law firm of Gordon, Hurwirz, et al. Armstrong retained the Gordon firm to initiate a $\$ 24$ million suit against Alpine, Capital Growth, and others for damages resulting from violation of the securities laws. McAlpin was President and Chairman of the Board of defendants Capital Growth Company and New Providence, a Bahamian corporation from which Capital Growth Fund was formcd. Prior to retaining the Gordon firm, Armstrong had secured the approval of the Securities and Exchange Commission and a district court judge for a screening procedure insulating Altman from the other members of the Gordon firm. McAlpin moved to disqualify the Gordon firm, and the district court denied the motion. An appeal to the Court of Appeals for the Second Circuit followed. The Second Circuit reversed.

26. 606 F.2d at 33 .

27. See note 21 supra. The jurisdiction that has reverted to the pre-1974 language is lllinois. See Illinois Code of Professional Responsibility DR 5-105(D), reprinted in 66 ILL. B.J. (1978) (specially numbered insert following page 396). 
solution does not guarantee, however, that the courts will go along. The District of Columbia Court of Appeals, the governing body for the integrated District of Columbia Bar, is currently struggling with the problem. ${ }^{28}$

One thing that stands out in this controversy is that the strict enforcement of a vicarious disqualification rule is essentially consistent with the principle of placing the interests of the chient first. We have seen this policy umiformly adhered to in each of the three controversial areas of lawyer-client relationships that have been examined.

Lawyers, like most liuman beings, are sensitive to criticism. It is therefore not surprising to learn that the American Bar Association has established a Commission on Evaluation of Professional Standards to investigate the controversy regarding ethics currently swirling around the legal profession and to make recommendations for change if necessary. The Commission, under the chairmanship of Robert J. Kutak, has labored long and hard to carry out its mandate and evidently has concluded that something rather drastic needs to be done about the situation. In August, 1979, just prior to the annual ABA convention in Dallas, the initial draft of a revised Code of Professional Responsibility was made public. ${ }^{29}$ It is small wonder that the draft was one of the nain topics of conversation at the convention; it represents a radical departure froin the present Code.

Unlike the present Code, the draft is written in the format of the restatements of the law, with blackletter headnotes setting forth the rules followed by paragraphs of explanation and illustration. Paragraph 1.4 admonishes the lawyer to represent the client with zeal, acting with vigor and persistence, ${ }^{30}$ but after that the draft innoses some definite limitations on obligations to the client.

After stating the importance of preserving client confidences, sub-

28. The Court has before it proposals ranging all the way from a variety of screening procedures to an application of section 207 of the federal conflict of interest law. See note 17 supra.

29. Shortly after the convention, the entire text of the initial rewrite was printed in Legal Times of Washington. See Legal Times 26-47.

30. 1.4 Representing client with zeal

(a) A lawyer shall act with vigor and persistence in representing a client. A lawyer may take any action in behalf of a client that is consistent with law and the rules of professional conduct. client if:

(c) A lawyer may limit the extent and purposes of the representation provided a and

(1) The client's rights under the client-lawyer relationship are not inpaired,

(2) The [c]lient consents after adequate disclosure of the limitation and of the client's rights in the relationslip.

Legal Times 28, col. 3. The expressions "mitiative and perserverance" might be preferable to

"vigor and persistence" in this context. 
paragraph 1.5(b) requires the lawyer to disclose information about a client-which presumably includes confidences-when necessary to prevent the client from committing an act that would seriously endanger a person, destroy property, or result in wrongful confinement, or when required by law or rules of professional conduct. ${ }^{31}$ The explanatory comments accompanying this paragraph nake it unmistakably clear that when the interests in continued protection of confidentiality come into conflict with the interests in preventing a deliberate, serious wrong, the latter interests should prevail. ${ }^{32}$

\section{Paragraph 1.13 of the draft deals with the preservation of confi-}

31. This subparagraph is set forth with an alternative third sentence. An alternative subparagraph (c) is also included. The full text of paragraph 1.5 is as follows:

1.5 Preserving confidentiality of information concerning client

In giving testimony or providing evidence concerning a client's affairs, a lawyer shall not disclose inatter concerning the client except as permitted under the apphicable law of evidentiary privilege. In other circumstances, a lawyer shall not disclose information about a client acquired in serving the client and in a professional capacity except as stated in subsections (a), (b), and (c).

(a) A lawyer shall disclose information about a client when directed to do so by the client and inay do so when the disclosure is necessary in the representation.

(b) A lawyer shall disclose information about a client only to the extent necessary: (1) To prevent the client froin coinunitting an act that would seriously endanger the life or safety of a person, result in wrongful detention or incarceration of a person or wrongful destruction of substantial property, or corrupt judicial or governmental procedure; sional conduct.

(2) When disclosure by the lawyer is required by law or the rules of profes-

(First Alternative)

(3) To prevent or rectify the consequences of a deliberately wrongful act by the client in which the lawyer's services are or were involved, except when the lawyer has been einployed after the commission of such an act to represent the client concerning the act or its consequences.

(c) A lawyer may disclose information about a client to the extent necessary to establish or collect the lawyer's fee or to defend against a charge against the lawyer of conduct wrongful to the client or of wrongful conduct in which the client was involved.

(Second Alternative)

(c) A lawyer may disclose information about a client to the extent necessary:

(1) To prevent or rectify the consequences of a deliberately wrongful act by the client in which the lawyer's services are or were involved, except when the lawyer has been einployed after the commission of such an act to represent the chient concerning the act or its consequences;

(2) To establish or collect the lawyer's fee or to defend agamst a charge against the lawyer of conduct wrongful to the client or of wrongful conduct in which the client was involved.

Legal Times 28, col. 4.

32. The pertinent parts of the explanation state:

Mandatory disclosure: preventing serious offense. The confidentiahty rule is subject to exceptions according primacy to interests other than those of the client. Sorne exceptions are mandatory in that the lawyer must make a disclosure; under others the lawyer inay make disclosure but is not obliged to do so.

A mandatory exception arises where the lawyer has definite knowledge that the client intends to commit a serious wrong and the lawyer can prevent its occurrence [sic] by making disclosure of infornation concerning the client. This exception parallels a quahfication to the attorney-client privilege. The acts to be prevented include hoinicide, of- 
dences of organizations such as corporations. ${ }^{33}$ After emphasizing that the lawyer retaimed by an organization owes his primary duty to that organization, the rule requires the lawyer to disclose serious wrongdoing by the corporation's governing body to those suffering injury or to appropriate regulatory authorities. Paragraph 1.13 thus requires counsel for an organization to "blow the whistle" on wrongdoing if all else fails, even at the cost of betraying confidences. If this provision is approved, the corporate lawyer will no longer be required to wring his hands in silence as he watches the organization be destroyed by the wrongful acts of its directors.

In handling the lawyer's role as adviser, the draft code forbids the lawyer to give advice that his client is likely to use to cause wrongful confinement of a person, destruction of property, fraud, or corrupt procedure. ${ }^{34}$ The draft code also deals with the responsibility of the law-

fenses against the person, willful destruction of property, and such crimes as bribery and perjury, which are offenses agaimst the administration of the law.

The value of legal counselling and maintenance of privacy for the client, great as it is, is outweighed by the importance of preventing these harms. Upon learning of the client's purpose the lawyer should counsel the chent agamst carrying it out and thereby try to prevent the harms while keeping the information confidential. Indeed, if the lawyer does not give such counsel, under some circumstances the lawyer could become personally liable for the client's conduct. If the client, thus having been warned, persists in the wrongful purpose, the imterests in conflict are those of continued protection of confdentiality and prevention of a dehberate, serious wrong. The latter interest should prevail.

Legal Times 29, col. 2.

33. The relevant parts of paragraph 1.13 are as follows:

1.13 Organization as client

A lawyer retamed by an organization represents the organization as distinct from its directors, officers, members, or shareholders.

(a) If in the course of representation a lawyer for an organization knows that an officer or other person associated with the organization is engaged in or intends action or a refusal to act that is legally improper and likely to result in significant harm to the organization, the lawyer shall take necessary measures to assure further consideration of the action or refusal to act. Such measures may include:

for it;

(1) Asking reconsideration of the matter by the person regularly responsible

(2) Referring the matter to higher authority in the organization;

(3) Seeking a separate legal opinion on the matter for presentation to appropriate authority in the organization;

thority;

(4) Reporting the inatter to the board of directors or similar governing au-

(5) Resigning.

(b) If an action or refusal to act by the board of directors or similar governing authority of an organization will im reasonable probability result in irreparable mjury to the organization, or in substantial mjury to a person having ownership or membership rights in the organization, and the action or refusal to act would be a violation of law for which no non-frivolous defense could be made, and corrective ineasures described in subsection (a) are ineffective, the lawyer shall take further measures necessary to prevent the violation, including giving notice to the imjured persons, making the lawyer's resignation known pubhicly, or reporting the matter to appropriate regulatory authority. The measures taken shall be such as reasonably appear to be as little disruptive, and involve least risk of disclosing client confidences, as possible.

Legal Times 33, col. 1.

34. Paragraph 2.3 is as follows: 
yer as advocate..$^{35}$ It is in this paragraph that the requirements of candor to the tribunal are laid down. These requirements constitute the most radical departure of the draft code from the counterpart provisions in the present Code of Professional Responsibility. Paragraph 3.2 of the draft makes it absolutely clear that, except in defending a criminal action, the lawyer must disclose facts, even those adverse to the interests of the chent, when such disclosure is required to correct a misapprehension resulting from a previous misrepresentation or when disclosure of the fact would probably have a substantial effect on the determination of a material issue of fact. In addition, the lawyer is not permitted to offer evidence known to be misleading or false. He is re-

2.3 Advice concerning wrongful conduct

A lawyer may advise a client of the probable consequences of engaging in conduct that is criminal, tortious, or otherwise legally wrongful, except as stated in this [s]ection.

(a) A lawyer shall not give advice that the lawyer reasonably can foresee will be used by the client to further a wrongful act that would seriously endanger the life or safety of a person, result in wrongful detention or incarceration of a person or wrongful destruction of subst[a]ntial property, corrupt judicial or governmental procedure, or constitute fraud.

(b) A lawyer may decline to give advice that might assist the client in any conduct that would violate the law, or, subject to the provisions of subsection 1.4, that the lawyer considers unjust.

Legal Times 35, col. 1.

35. The provisions of paragraph 3.2 of the draft code pertinent to this discussion are as follows:

3.2 Candor toward the tribunal

In presenting a cause, a lawyer shall be properly candid to the tribunal.

(a) A lawyer shall not:

(1) File a coinplaint, motion, or other pleading unless according to the law-

yer's belief there is good ground to support it;

(2) Make a knowing misrepresentation of fact;

(3) Fail to disclose a fact, even if the fact is adverse, when:

disclose the fact; or

(i) Law or the rules of professional conduct require the the lawyer to

(ii) Disclosure of the fact is necessary to correct a misapprehension resulting from a previous representation the lawyer has made to the court; or

(iii) Disclosure of the fact would probably have a substantial effect on the determination of a material issue of fact, except as provided in subsection (c).

(4) Except as provided in subsection (c), offer evidence that the lawyer knows beyond a reasonable doubt to be false or fabricated, or offer without suitable explanation evidence that the lawyer knows is substantially misleading. If a lawyer discovers that evi[d]ence or testimony that the lawyer has presented is false or fabricated, it is the lawyer's duty to disclose that fact and to take suitable measures to rectify the consequences, even if doing so requires disclosure of a confidence of the client or disclosure that the client is implicated in the falsification or fabrication.

(5) Make a representation about existing legal authority that the lawyer knows to be inaceurate or so incoinplete as to be substantially misleading, or fail to disclose legal authority known to the lawyer which would probably have a substantial effect on the determination of a material issue of law.

(b) Except as provided in subsection (c), a lawyer unay proffer to another party evidence favorable to that party and may refuse to offer evidence in the veracity or authenticity of which the lawyer does not beheve.

(c) A lawyer for a defendant im a criminal case:

(1) Is not required to apprise the prosecutor or the court of evidence adverse to the accused....

Legal Tines 36, col. 1. 
quired to disclose the existence of false evidence or testimony and to take suitable measures to rectify the consequences of its previous admission, even if so doing requires betrayal of client confidences.

The explanation of these rules emphasizes their primary thrust: the lawyer must not become an instrument for deceiving the court, even if client confidences must be disclosed. To allow the lawyer to assume such a role would subvert the integrity of the adversary process and might cause the lawyer to become a party to a fraud upon the court. This paragraph dramatically illustrates the overall policy of the draft code in placing the interests of the justice system in a position of primacy over the interests of the client when the two interests conflict. ${ }^{36}$

Section 7 of the draft code addresses the responsibilities of law firms and associations of lawyers. Although adopting the basic premise that lawyers must not place themselves in substantial conflict of interest positions with respect to clients, paragraph 7.1 of this section does not lay down any sweeping rule regarding vicarious disquahification such as that found in DR 5-105(D) of the present code. ${ }^{37}$ Instead, the explanation of the rule emphasizes that the paramount considerations in any disqualification inatter are preservation of client confidences and avoidance of situations that would place the lawyer in positions adverse to any client. The section seems to advocate a case-by-case approach to tlie disqualification issue based on a careful assessment of the two factors described. It does, however, place the burden of showing that no conflict of interest exists on the lawyer whose disqualification is in question. This unore realistic manner of dealing with vicarious disqualification in the draft code would probably resolve most of the difficulties arising from the conflict of interest dilemma presently bedeviling the governing bodies of the practicing bar.

36. The explanation for paragraph 3.2 even goes so far as to state that the lawyer for the defendant in a crimmal case must disclose the client's perjury if all other efforts to prevent the commission of the perjury have failed. Legal Times 36, col. 4 .

37. See note 14 supra. The text of paragrapl 7.1 of the draft code reads as follows:

7.1 Vicarious disqualification

(a) When two lawyers are associated in practice, they may not represent multiple clients when a lawyer practicing alone might not properly do so.

(b) When two lawyers have been associated in practice and the lawyers then terminate their association, neitlier they nor any otlier lawyer with whom they subsequently become associated may undertake representation that imvolves:

(1) A significant risk of disclosing confidences of a client or making improper use of information to the disadvantage of a former chent; or

(2) A lawyer's assuming significant participation or responsibility for asserting a position adverse to a client for whom the lawyer had previously assumed significant participation or responsibility in the same or a substantially related matter.

(c) A disqualification prescribed by this section may be waived by the consent of the affected client upon adequate disclosure.

Legal Times 43-44. 
The draft code is an important document: it changes some signifcant policies regarding the responsibilities of lawyers that have been in effect for many years. The proposed code deserves careful consideration and thorough discussion by every lawyer. Undoubtedly this initial draft needs considerable refinement, but, it is hoped that the process of refinement will not render the proposed code an unintelligible document of meaningless equivocation.

The fact that the American Bar Association considers it iniportant to conduct a reevaluation of professional standards after only ten years clearly indicates that serious problems exist. Only by taking a forthright and realistic approach to the solution of these problems will it be possible to put the legal profession in a posture adequate to meet the challenges of the future. 